Jurnal Kesehatan Terpadu (Integrated Health Journal)

Vol. 11 No. 2, November 2020 (94-100)

ISSN 1978-7766 (Print) and ISSN 2597-9566 (Online)

Journal homepage: https://www.jurnalpoltekkesmaluku.com/index.php/JKT

\title{
Pengaruh Model Pendampingan Deteksi Dini terhadap Kemampuan Guru PAUD dalam Melaksanakan Deteksi Dini Pertumbuhan dan Perkembangan Anak PAUD di Wilayah Kerja Puskesmas Beji Depok \\ The Effect of Early Detection Assistance Model on the Ability of Early Childhood Education Teachers in Implementing Early Detection of Early Childhood Growth and Development in the Working Area of the Beji Public Health Center, Depok
}

\author{
Suryati B ${ }^{1}$, Bara Miradwiyana ${ }^{1}$ \\ ${ }^{1}$ Jurusan Keperawatan Poltekkes Kemenkes Jakarta 1, Jalan Wijaya Kusuma 47-48, Pd. Labu, \\ Cilandak, Jakarta Selatan, DKI Jakarta \\ E-mail Korespondensi: suryati_suripto@yahoo.com
}

\begin{abstract}
Impaired growth and development of children can be identified by early detection as prevention, prevention, stimulation and development. This study aims to determine the effect of early detection assistance models on the ability of early childhood education (PAUD) teachers in implementing early detection of early childhood growth and development. The research method uses pretest and posttest design with control group. Providing training and mentoring for PAUD teachers using the Stimulation of Detection and Early Intervention Growing Swell (SDIDTK)/ Child Development Pre-screening Questionnaire (KPSP) for the intervention group while for the control group for PAUD teachers by being given a KPSP booklet after the posttest. The results of the analysis showed that there were differences in scores of PAUD teachers' knowledge and skills in stimulating early childhood growth and development $(\mathrm{p}=0.001)$ between the intervention group and the control group after the mentoring model intervention. The knowledge of PAUD teachers who are given a mentoring model is better than the control group, there are significant differences in improving the ability of PAUD teachers to do early detection in children compared to the control group. PAUD teachers who are given the intervention of the mentoring model.
\end{abstract}

Keywords: Early childhood education, early detection, growth and development

\begin{abstract}
ABSTRAK
Gangguan pertumbuhan dan perkembangan anak dapat diketahui dengan dilakukan deteksi dini perkembangan sebagai upaya pencegahan, stimulasi, dan penyembuhan. Penelitian ini bertujuan untuk mengetahui pengaruh model pendampingan deteksi dini terhadap kemampuan guru PAUD dalam melaksanakan deteksi dini pertumbuhan dan perkembangan anak PAUD. Metode penelitian menggunakan pretest dan posttest design with control group. Pemberian pelatihan dan pendampingan terhadap Guru PAUD dengan memakai Pedoman Stimulasi Deteksi dan Intervensi Dini Tumbuh Kembang (SDIDTK)/ Kuesioner Pra Skrining Perkembangan (KPSP) kelompok intervensi sedangkan untuk kelompok kontrol pada Guru PAUD dengan diberi pegangan booklet KPSP sesudah posttest. Hasil analisis menunjukkan bahwa terdapat perbedaan skor pengetahuan dan keterampilan guru PAUD dalam stimulasi tumbuh kembang anak usia dini $(\mathrm{p}=0.001)$ antara kelompok intervensi dan kelompok kontrol setelah dilakukan intervensi model pendampingan. Analisis multivariat tidak bisa dilakukan karena hanya 1 variabel yang berpengaruh dari hasil analisis bivariat. Pengetahuan guru PAUD yang diberi model pendampingan lebih baik dibandingkan dengan kelompok kontrol. Ada perbedaan yang berarti dalam meningkatkan kemampuan guru PAUD/ TK untuk melakukan deteksi dini pada anak dibandingkan dengan kelompok kontrol guru PAUD yang diberi intervensi model pendampingan.
\end{abstract}

Kata kunci: Deteksi awal, pendidikan anak usia dini, PAUD, tumbuh kembang 


\section{PENDAHULUAN}

Setiap anak akan mengalami tumbuh dan kembang mulai konsepsi sampai masa remaja. Anak mempunyai ciri pertumbuhan dan perkembangan yang sesuai tingkat usia. Masa utama dalam tumbuh kembang anak adalah masa balita, pada masa ini merupakan pertumbuhan dasar yang akan mempengaruhi dan menentukan perkembangan anak berikutnya.

Perkembangan adalah proses bertambahnya kemampuan keterampilan (skill) dalam struktur dan fungsi tubuh yang bersifat lebih kompleks dengan pola yang teratur dan dapat diramalkan. Hal ini merupakan hasil dari proses pematangan. Peristiwa perkembangan berkaitan dengan masalah psikologis kemampuan gerak kasar dan halus, intelektual, sosial dan emosional.

Pertumbuhan suatu proses hidup manusia terkait masalah perubahan dalam besar, jumlah, ukuran organ atau individu. Semua perubahan dapat dilihat melalui perubahan ukuran berat, panjang, dan besar lingkar kepala.

Pertumbuhan dan perkembangan anak dipengaruhi oleh faktor genetik dan faktor lingkungan. Pemahaman pertumbuhan dan perkembangan anak sesuai tingkat usia memberikan peluang yang besar bagi orangtua, guru maupun orang dewasa lain yang bertanggungjawab akan anak tersebut untuk dapat memberikan pengasuhan dan perawatan anak secara efektif dan tepat.

Pencapaian kemampuan setiap anak bisa berbeda-beda. Namun, ada patokan umum tentang kemampuan yang perlu dicapai seorang anak pada umur tersebut. Patokan agar anak yang belum mencapai tahap kemampuan tertentu perlu distimulasi dengan berbagai kemampuan untuk dapat mencapai perkembangan yang optimal. Aspek yang harus disiapkan dalam menghadapi masa depan anak meliputi perkembangan gerak kasar, gerak halus, bahasa dan sosial (kemampuan bergaul). Kemungkinan adanya gangguan/ penyimpangan dalam aspek tersebut dapat dicegah sedini mungkin dengan melakukan pemeriksaan deteksi dini tumbuh kembang anak.

Upaya deteksi dini dilakukan secara menyeluruh untuk menemukan penyimpangan gangguan masalah tumbuh kembang dan mengetahui mengenai faktor risiko, baik fisik maupun psikologis. Untuk tercapainya tumbuh kembang anak yang optimal perlu dilakukan deteksi dini perkembangan sebagai upaya pencegahan, stimulasi, dan penyembuhan. Hal ini perlu dikoordinasikan oleh tenaga kesehatan, orangtua/ wali, guru PAUD, dan kader. Hasil Penelitian Rosalia dkk, ${ }^{(1)}$ ditemukan keterlambatan bicara 55,1\% pada anak usia 25-36 bulan. Gangguan mental emosional 74,2\% pada anak usia 3-5 tahun. ${ }^{(2)}$ Solihin $\mathrm{dkk},{ }^{(3)}$ menemukan bahwa dari 73 anak yang diteliti terdapat 54,8\% anak dikategorikan perkembangan kognitifnya tergolong rendah, begitupun dengan perkembangan motorik halusnya (68,5\%). Menurut Soetjiningsih ${ }^{(4)}$, tumbuh kembang adalah dua peristiwa yang sifatnya berbeda, tetapi saling berkaitan dan sulit dipisahkan, yaitu pertumbuhan dan perkembangan.

Aspek tumbuh kembang pada masa anak merupakan suatu hal yang sangat penting, yang sering diabaikan oleh tenaga kesehatan khususnya di lapangan ${ }^{(5)}$. Banyak faktor yang menyebabkan hal tersebut terjadi termasuk diantaranya adalah kurangnya tenaga kesehatan untuk melakukannya. Sebagai solusi, pembinaan tumbuh kembang anak diintegrasikan dengan fasilitas Pendidikan Anak Usia Dini (PAUD) yaitu Kelompok Bermain dan Taman KanakKanak yang kini marak diikuti oleh para balita.

Orang tua dan guru PAUD merupakan salah satu elemen yang paling penting untuk dapat memberikan stimulasi yang tepat dan mengetahui adanya penyimpangan pertumbuhan dan perkembangan anak pada usia dini ${ }^{(6)}$. Keberhasilan tumbuh kembang anak pada usia dini merupakan dasar perkembangan anak selanjutnya, namun demikian banyak kendala yang dihadapi oleh guru PAUD dalam melaksanakanan kegiatan stimulasi, deteksi dan intervensi dini tumbuh kembang anak ${ }^{(7)}$.

Permasalahan yang dihadapi oleh guru PAUD di wilayah kerja Puskesmas kecamatan Beji Depok dalam kegiatan SDIDTK adalah kurangnya pengetahuan dan keterampilan guru. Untuk meningkatkan pengetahuan dan keterampilan guru PAUD dalam stimulasi, deteksi dan intervensi dini tumbuh kembang anak prasekolah tidak cukup hanya melalui penyuluhan tetapi 
perlu pelatihan dan pendampingan secara terencana dan terstruktur. Oleh karena itu solusi yang tepat untuk mengatasi permasalahan tersebut adalah dengan meningkatkan pengetahuan dan keterampilan guru PAUD melalui pelatihan dan pendampingan dalam melaksanakan kegiatan SDIDTK.

Tindakan melakukan deteksi dini masalah tumbuh kembang merupakan screening atau pemeriksaan secara dini adanya penyimpangan tumbuh kembang anak termasuk mencatat setiap keluhan orang tua terhadap gangguan tumbuh kembang anaknya. ${ }^{(8)}$

\section{METODE PENELITIAN}

Jenis penelitian eksperimen ini menggunakan metode pretest dan posttest design with control group. Dilaksanakan pada bulan Juli-Oktober 2018 di wilayah kerja Puskesmas Beji Depok. Populasi penelitian ini adalah guru PAUD di wilayah kerja Puskesmas Beji Depok. Jumlah sampel yang digunakan adalah 35 responden yang masuk dalam kelompok intervensi dan 35 responden yang masuk dalam kelompok kontrol. Pada kelompok intervensi diberikan pelatihan dan pendampingan dalam melakukan deteksi tumbuh kembang. Kelompok kontrol dibiarkan melakukan deteksi dini tumbuh kembang tanpa pelatihan dan pendampingan. Dilakukan pretest sebelum dan posttest sesudah melakukan deteksi dini tumbuh kembang. Pengolahan data dilakukan dalam tahap-tahap editing, coding, processing, cleaning dan tabulating. Analisis data dilakukan dengan menggunakan program SPSS, menggunakan Paired t- Test untuk data berpasangan yang terdistribusi normal, analisis bivariat dengan uji chi square dan analisis multivariate menggunakan uji MANCOVA.

\section{HASIL}

\section{A. Analisa Univariat}

\section{Karakteristik Responden}

Tabel 1. Distribusi Pendidikan Responden $(n=35)$

\begin{tabular}{|c|c|c|c|c|c|c|}
\hline \multirow{2}{*}{ No } & \multirow{2}{*}{ Variabel } & \multirow{2}{*}{ Kategori } & \multicolumn{2}{|c|}{ Intervensi } & \multicolumn{2}{|c|}{ Kontrol } \\
\hline & & & $\mathbf{n}$ & $\%$ & $\mathbf{n}$ & $\%$ \\
\hline \multirow{2}{*}{1} & \multirow{2}{*}{ Pendidikan } & Pend Dasar/Menengah & 12 & 34.3 & 17 & 48.6 \\
\hline & & Pendidikan Tinggi & 23 & 65.7 & 18 & 51.4 \\
\hline
\end{tabular}

Tabel 2. Distribusi Usia, Lama Mengajar Responden ( $\mathbf{n}=35)$

\begin{tabular}{|c|c|c|c|c|c|c|c|c|c|}
\hline \multirow{2}{*}{ No } & \multirow{2}{*}{ Variabel } & \multicolumn{4}{|c|}{ Intervensi } & \multicolumn{4}{|c|}{ Kontrol } \\
\hline & & Mean & Median & Min & Max & Mean & Median & Min & Max \\
\hline 1 & Usia & 33.63 & 34.50 & 19 & 53 & 35.71 & 37 & 19 & 52 \\
\hline 2 & $\begin{array}{l}\text { Lama } \\
\text { mengajar }\end{array}$ & 8.71 & 6.00 & 1 & 35 & 8.51 & 8.00 & 1 & 21 \\
\hline
\end{tabular}

Berdasarkan tabel 1 dan 2, dapat disimpulkan bahwa sebagian besar responden pada kelompok intervensi adalah guru PAUD dengan katagori usia dewasa awal dan memiliki pengalaman mengajar rata-rata 8.71 tahun. Pada kelompok kontrol sebagian besar guru PAUD juga masuk dalam katagori usia dewasa awal dengan latar belakang berpendidikan tinggi dan memiliki pengalaman mengajar rata-rata 8.51 tahun. 


\section{Kesetaraan Responden}

Tabel 3. Analisis Kesetaraan Tingkat Pendidikan antar Kelompok

\begin{tabular}{|c|c|c|c|c|c|}
\hline \multirow{2}{*}{ Variabel } & \multicolumn{2}{|c|}{ Kel. Intervensi } & \multicolumn{2}{|c|}{ Kel. Kontrol } & \multirow{2}{*}{ p-value } \\
\hline & $\mathbf{n}$ & $\%$ & $\mathbf{n}$ & $\%$ & \\
\hline $\begin{array}{l}\text { 1. Pendidikan } \\
\text { dasar/Menengah }\end{array}$ & 12 & 34.3 & 17 & 48.6 & 0.225 \\
\hline 2. Pendidikan Tinggi & 23 & 65.7 & 18 & 51.4 & \\
\hline
\end{tabular}

Berdasarkan tabel 3, diketahui bahwa dari hasil analisis ada perbedaan yang bermakna pada tingkat pendidikan guru PAUD antara kelompok intervensi dan kelompok kontrol. Kedua kelompok sebagian besar memiliki tingkat pendidikan yaitu berpendidikan tinggi.

Tabel 4. Analisis Kesetaraan Usia dan Lama Pengalaman Kerja antar Kelompok

\begin{tabular}{llcccc}
\hline \multicolumn{1}{c}{ Variabel } & Kelompok & N & Mean & SD & p-value \\
\hline Usia & Intervensi & 35 & 33.62 & 9.755 & \multirow{2}{*}{0.394} \\
& Kontrol & 35 & 35.71 & 8.94 & \\
\hline Lama pengalaman & Intervensi & 35 & 8.71 & 9.195 & \multirow{2}{*}{0.909} \\
kerja & Kontrol & 35 & 8.51 & 6.294 & \\
\hline
\end{tabular}

Berdasarkan tabel 4, diketahui bahwa dari hasil analisis ditemukan tidak ada perbedaan usia dan lama pengalaman mengajar antara kelompok intervensi dan kelompok kontrol.

\section{B. Analisia Bivariat}

1. Perbedaan skor pengetahuan dan keterampilan Guru PAUD terhadap tumbuh kembang anak usia dini sebelum dan sesudah intervensi pada kelompok intervensi dan kontrol

Tabel 5. Analisis Skor Pengetahuan dan Keterampilan Sebelum dan Sesudah Intervensi Model Pendampingan Guru PAUD

\begin{tabular}{llccccc}
\hline \multicolumn{1}{c}{ Variabel } & \multicolumn{1}{c}{ Kelompok } & Mean & SD & 95\% CI & T & p-value \\
\hline \multirow{5}{*}{$\begin{array}{l}\text { Skor } \\
\text { pengetahuan }\end{array}$} & Sel. Intervensi & & & & & \\
& Sesudah & 10.828 & 1.105 & $-1.065-0.306$ & -3.670 & 0.001 \\
& Selisih & 11.514 & & & & \\
\cline { 2 - 7 } & Kel. Kontrol & -0.685 & & & & \\
& Sebelum & 11.342 & 1.578 & $-0.056-1.028$ & 1.820 & 0.078 \\
& Sesudah & 10.857 & & & & \\
& Selisih & 0.485 & & & & \\
Kel. Intervensi & & & & & \\
Kkor & Sebelum & 7.714 & 1.278 & $-1.324-0.446$ & -4.100 & 0.000 \\
& Sesudah & 8.600 & & & & \\
& Selisih & -0.885 & & & & \\
\cline { 2 - 7 } & Kel. Kontrol & & & & & \\
& Sebelum & 8.514 & 1.078 & $-0.056-0.684$ & 1.724 & 0.094 \\
& Sesudah & 8.200 & & & & \\
& Selisih & 0.314 & & & &
\end{tabular}

Berdasarkan tabel 5, diketahui bahwa dari hasil analisis menunjukkan terdapat perbedaan bermakna skor pengetahuan tentang tumbuh kembang anak usia dini pada kelompok intervensi dan kelompok sebelum dan sesudah intervensi model pendampingan $(\mathrm{p}=0,001)$, dan selisih nilai 
rata-rata peningkatan skor pengetahuan pada kelompok intervensi lebih besar (nilai selisih=3.670) sedangkan pada kelompok kontrol rata-rata selisih skor sebesar 1.820. Analisis menunjukkan terdapat perbedaan bermakna skor keterampilan tentang tumbuh kembang anak usia dini pada kelompok intervensi dan kelompok sebelum dan sesudah intervensi model pendampingan (nilai $\mathrm{p}=0,000$ ), dan selisih nilai rata-rata peningkatan skor keterampilan pada kelompok intervensi lebih besar (nilai selisih=4.100) sedangkan pada kelompok kontrol ratarata selisih skor sebesar 1.724 .

\section{Perbedaan skor pengetahuan dan keterampilan dalam stimulasi tumbuh kembang} anak usia dini antar kelompok.

Tabel 6. Analisis Skor Pengetahuan dan Keterampilan dalam Stimulasi Tumbuh Kembang Anak Usia Dini Sesudah Intervensi antar Kelompok

\begin{tabular}{llllcccc}
\hline \multicolumn{1}{c}{ Variabel } & Kelompok & $\mathbf{N}$ & Mean & SD & 95\% CI & F & p-value \\
\hline Pengetahuan & Intervensi & 35 & 0.685 & 1.105 & \multirow{2}{*}{$1.822-0.520$} & \multirow{2}{*}{0.314} & \multirow{2}{*}{0.001} \\
& Kontrol & 35 & 0.485 & 1.578 & & \\
\hline Keterampila & Intervensi & 35 & 0.885 & 1.278 & \multirow{2}{*}{$1.764-0.635$} & \multirow{2}{*}{0.291} & \multirow{2}{*}{0.000} \\
& Kontrol & 35 & 0.314 & 1.078 & & & \\
\hline
\end{tabular}

Berdasarkan tabel 6, diketahui bahwa dari hasil analisis menunjukkan bahwa terdapat perbedaan skor pengetahuan dan keterampilan guru PAUD dalam stimulasi tumbuh kembang anak usia dini $(\mathrm{p}=0.001)$ antara kelompok intervensi dan kelompok kontrol setelah dilakukan intervensi model pendampingan.

\section{Analisia Multivariat}

Analisis multivariat tidak bisa dilakukan karena hanya 1 variabel yang berpengaruh dari hasil analisis bivariat yaitu variabel pengetahuan.

\section{BAHASAN}

\section{Kesetaraan Responden}

Hasil penelitian tentang kesetaraan guru PAUD antara kelompok kontrol dan kelompok intervensi menunjukan tidak ada perbedaan yang bermakna dalam hal jenjang pendidikan. Ratarata jenjang pendidikan guru responden adalah pendidikan tinggi. Hal ini membuktikan bahwa semua guru yang menjadi responden penelitian mempunyai tingkat pendidikan yang tidak jauh berbeda dan mempunyai kompetensi yang standar sebagai guru PAUD.

Kompetensi pendidikan responden sesuai dengan persyaratan untuk menjadi tenaga pendidik PAUD di Indonesia diatur dalam Permendiknas No 16 tahun 2007 tentang standar kualifikasi akademik dan kompetensi guru. Permendiknas menjelaskan bahwa untuk menjadi tenaga pendidik PAUD seseorang harus memiliki kualifikasi akademik minimum diploma empat (D-IV) atau sarjana (S-1) dalam bidang pendidikan atau psikologi yang diperoleh dari program studi yang terakreditasi.

Pasal 10 ayat (1), Undang-Undang Nomor 14 Tahun 2005 tentang Guru dan Dosen, menyebutkan "Kompetensi guru sebagaimana dimaksud dalam Pasal 8 meliputi kompetensi pedagogik, kompetensi kepribadian, kompetensi sosial, dan kompetensi profesional yang diperoleh melalui pendidikan profesi".

Rata-rata usia antara kelompok kontrol dengan kelompok intervensi juga tidak terlihat perbedaan yang bermakna. Usia semua responden sebagian besar sudah memasuki akhir usia dewasa awal. Hurlock ${ }^{(5)}$ mengatakan bahwa dewasa awal dimulai pada usia 18 tahun sampai usia 40 tahun. Salah satu karakteristik masa dewasa awal adalah masa ini dikenal sebagai usia reproduktif. Masa dewasa awal adalah masa beralihnya pandangan egosentris menjadi sikap 
yang berempati. Rata-rata responden berusia 30 tahunan keatas yang berarti sudah cukup matang dalam bersikap dan berpikir secara dewasa dan mampu membimbing anak asuhan kearah yang lebih baik.

Lama pengalaman kerja antara kelompok kontrol dan kelompok intervensi tidak menunjukan perbedaan yang bermakna. Pengalaman bekerja selama delapan tahun sudah cukup dianggap berpengalaman dalam melakukan pekerjaannya. Guru yang sudah lama mengajar tentunya lebih berpengalaman dalam menghadapi berbagai macam tingkah laku anak usia dini dibandingkan dengan guru pemula dengan pengalaman belajar dibawah satu tahun. Walaupun lama mengajar bukanlah faktor utama yang menyebabkan seorang guru gagal meningkatkan keprofesionalannya.

Hasil analisis tentang kesetaraan karakteristik responden menunjukan tidak ada perbedaan yang bermakna antara kelompok intervensi dan kelompok kontrol. Hal ini berarti karakteristik antara kedua responden mendekati sama dengan kata lain terkontrol. Hasil ini juga membuat hasil penelitian tidak menjadi bias yang kemungkinan bisa disebabkan oleh tidak setaranya karakteristik antara kedua kelompok responden.

\section{Pengaruh intervensi dalam meningkatan pengetahuan dan keterampilan}

Dalam penelitian ini intervensi yang dilakukan adalah memberi pelatihan tentang cara mendeteksi dini tumbuh kembang pada anak dan melakukan pendampingan. Pretest dan posttest dilakukan sebelum dan setelah dilakukan pelatihan. Hasil penelitian menunjukan ada perbedaan yang signifikan pada kelompok intervensi dalam hal pengetahuan dan keterampilan sebelum dan setelah dilakukan pelatihan. Peningkatan pengetahuan dan keterampilan meningkat setelah diberi pelatihan dan pendampingan.

Pretest dilakukan sebelum pemberian materi pada kelompok intervensi. Pada kelompok kontrol pretest diberikan sebelum melakukan keterampilan pemeriksaan pertumbuhan dan perkembangan pada anak. Pada kelompok intervensi dilakukan pendampingan dalam melakukan deteksi tumbuh kembang selama tiga kali tindakan. Pada kelompok kontrol pelaksanaan pemeriksaan dilakukan secara mandiri tanpa pendampingan. Evaluasi dilakukan setelah tahap pendampingan selesai. Peneliti melakukan observasi pada responden dalam pelaksanaan deteksi tumbuh kembang anak secara mandiri baik pada kelompok intervensi maupun kelompok kontrol.

Hasil menunjukan bahwa responden pada kelompok intervensi lebih terlihat perubahan kemajuan dalam hal pengetahuan dan keterampilan dibandingkan dengan kelompok kontrol. Pada kelompok kontrol terjadi peningkatan sedikit yang tidak bermakna dilihat dari hasil evaluasi akhir.

Hasil pretest dan posttest menunjukan bahwa pemberian materi dalam pelatihan penting untuk meningkatkan pengetahuan peserta. Hal ini sesuai dengan teori bahwa setelah seseorang mengalami stimulus atau objek kesehatan, kemudian mengadakan penilaian atau pendapat terhadap hal yang diketahui, proses selanjutnya diharapkan dapat melaksanakan atau mempraktikan hal yang diketahui dan disikapi. ${ }^{(10)}$ Pendidikan kesehatan salah satunya dengan pelatihan merupakan proses perubahan, yang bertujuan untuk mengubah individu, kelompok dan masyrakat menuju hal- hal yang positif secara terencana melalui proses belajar. Perubahan tersebut mencakup pengetahuan, sikap dan keterampilan. ${ }^{(19)}$

Kelompok yang dilakukan intervensi model pendampingan tampak lebih percaya diri pada saat kegiatan deteksi tumbuh kembang pada anak. Kondisi tersebut membuat hasil evaluasi kelompok intervensi lebih baik dibandingkan dengan kelompok kontrol. Hal ini sesuai dengan tujuan dari model pendampingan yaitu dapat meningkatkan kompetensi guru lebih efektif setelah dilakukan pendampingan.

Menurut Purwadarminta, pendampingan adalah suatu proses dalam menyertai dan menemani secara dekat, bersahabat dan bersaudara, serta hidup bersama-sama dalam suka dan duka, bahu membahu dalam menghadapi kehidupan dalam mencapai tujuan bersama yang diinginkan. Maksud pola pendampingan adalah kegiatan membelajarkan kelompok yang 
berangkat dari kebutuhan dan kemampuan mereka atas dasar interaksi semua anggota dalam kelompok serta kesetiakawanan antara kelompok dalam rangka meningkatkan kesejahteraannya. ${ }^{(3)}$ Pengertian ini menunjukan bahwa pendampingan merupakan kegiatan untuk membelajarkan sekelompok orang yang berawal dari kebutuhan, dan potensi mereka, atas dasar adanya interaksi dari, oleh, dan untuk anggota kelompok.

Pendampingan dalam penelitian ini dilakukan oleh tim peneliti dengan anggota atau fasilitatornya sebagian dibantu dari tenaga kesehatan yang berasal dari Puskesmas Kecamatan Beji. Model pendampingan dalam penelitian ini membuktikan sangat diperlukan sebagai salah satu metode pembelajaran atau pelatihan untuk meningkatkan kompetensi peserta didik. Hasil penelitian ini menunjukkan peningkatan pengetahuan dan keterampilan jauh lebih bermakna pada kelompok intervensi dibandingkan dengan kelompok kontrol.

\section{SIMPULAN}

Hasil penelitian setelah diberi pelatihan menunjukan ada perbedaan yang berarti dalam pengetahuan Guru PAUD dalam kegiatan deteksi dini pada kelompok intervensi dan kontrol. Pengetahuan Guru PAUD yang diberi model pendampingan lebih baik dibandingkan dengan kelompok kontrol, ada perbedaan dalam meningkatkan kemampuan Guru PAUD/ TK untuk melakukan deteksi dini pada pada anak dibandingkan dengan kelompok kontrol.Guru PAUD yang diberi intervensi model pendampingan terlihat lebih trampil dibandingkan dengan kelompok kontrol.

Karakteristik responden yaitu pendidikan, umur dan lama mengajar tidak terlalu berpengaruh pada peningkatan pengetahuan dan keterampilan guru PAUD/ TK dalam memahami dan melakukan pemeriksaan deteksi dini tumbuh kembang pada anak. Hal ini disebabkan rata-rata responden mempunyai tingkat pendidikan yang sama, umur yang tidak terlalu jauh berbeda serta masa kerja yang hampir sama.

\section{SARAN}

Guru PAUD/ TK perlu mengetahui bagaimana cara melakukan deteksi dini tumbuh kembang pada anak. Kemampuan tersebut dapat mudah dipahami dan dilakukan dengan mengikuti pelatihan dan dilakukan pendampingan. Puskesmas disini yang harus berperan dan bertanggung jawab untuk meningkatkan pengetahuan dan keterampilan Guru PAUD/ TK di wilayah kerjanya.

Peran aktif Puskesmas akan membantu dalam meningkatkan status kesehatan anak. Puskesmas menjadi rujukan pertama bila di PAUD/ TK terdeteksi anak balita yang mengalami gangguan pertumbuhan dan perkembangan. Diharapkan Puskesmas dapat menindaklanjuti pemberian latihan dan pendampingan pada guru PAUD untuk melakukan deteksi dini tumbuh kembang anak.

\section{RUJUKAN}

1. Rosalia D. Prevalensi Dan Karakteristik Keterlambatan Bicara Pada Anak Prasekolah Di TPA Werdhi Kumara I Dengan Early Language Milestone Scale-2. Ilmu Kesehat Anak. 2012;I No.1.

2. Farida LN, Naviati E, Keperawatan J, Kedokteran F, Diponegoro U. Mental Emosional Pada Anak Usia Prasekolah. 2013;222-8.

3. Solihin D. Kajian Antara Status Gizi, Perkembangan Kognitif dan Perkembangan Motorik Pada Anak Usia Prasekolah. Penelit Gizi dan Makanan. 2013;36.

4. Soetjiningsih. Tumbuh Kembang Anak. 2nd ed. Jakarta: EGC; 2014.

5. Nursalam D. Asuhan Keperawatan Bayi dan Anak. Jakarta: Salemba Medika; 2013.

6. Christi et al. Hubungan Pengetahuan Ibu tentang Stimulasi Dini dengan Perkembangan motorik usia 6-24 bulan. Pustaka Kesehat. 2013;1 no 1.

7. Ummah F, Turlina L, Kusbiantoro D. Optimalisasi Peran Guru PAUD Untuk Meningkatkan 
Kualitas Tumbuh Kembang Anak Prasekolah. 2016;147-54.

8. RI. D. Pedoman pelaksanaan stimulasi, deteksi, dan intervensi tumbuh kembang anak. Jakarta:Kemenkes RI; 2016.

9. Hurlock EB. Psikologi Perkembangan: Suatu Pendekatan Sepanjang Rentang Kehidupan. Jakarta: Erlangga; 2000.

10. Notoatmojo. Metodologi Penelitian Kesehatan. Jakarta: Rineka Cipta; 1997.

11. Saidah, E.S. Pentingnya Stimulasi Mental Dini. J Ilmiah PendidikanAnak Usia Dini. No.01.hlm. 50-55, 2003

12. Arikunto, S.. Prosedur Penelitian Suatu Pendekatan Praktek. $5^{\text {th }}$ rev ed.. Jakarta: Rineka Cipta; 2008

13. Fida dan Maya. Pengantar ilmu kesehatan anak. Jogjakarta: DMedika; 2012

14. Hidayat, A. Pengantar Ilmu Keperawatan Anak 1. Salemba Medika: Jakarta; 2008

15. Desna, donate. Pertumbuhan Dan Perkembangan Anak Usia toddler.; 2014. (http://donatadesna.blogspot.com diakses pada 12 november 2014pukul 08.00 WIB)

16. Endah.. Aspek Perkembangan Motorik Dan KeterhubungannyaDengan Aspek Fisik Dan Intelektual Anak.;2008. (http://parentingislami.wordpress.com diakses 21 November 2014 )

17. Nursalam.. Konsep Penerapan Metodologi Penelitian IlmuKeperawatan. Salemba Medika: Jakarta; 2003

18. Santoso, Heru.. Petunjuk Praktis Denver Development ScreeningTest. Jakarta: EGC; 2009

19. Desna, donate. Pertumbuhan Dan Perkembangan Anak Usia toddler.; 2014. (http://donatadesna.blogspot.com diakses pada 12 november 2014pukul 08.00 WIB)

20. Santrock, J. Perkembangan anak jilid 2. Mila R, Anna K, Translator. Jakarta: Erlangga; 2007

21. Soedjatmiko. Tumbuh Kembang Anak. Jakarta: EGC; 2008 